\title{
Yield Performance of Two HYV Transplant Aman Rice under Different Nutrient Management Practices
}

\author{
Rajib Sarker $^{1,2, a}$, Newton Chandra Paul ${ }^{3, b}$, Md. Romij Uddin ${ }^{1, c}$, Swapan Kumar Paul ${ }^{1, d, *}$ \\ ${ }^{1}$ Department of Agronomy, Bangladesh Agricultural University, Mymensingh 2202, Bangladesh \\ ${ }^{2}$ Agriculture Training Institute, Sherpur, Bangladesh \\ ${ }^{3}$ Department of Agronomy, Khulna Agricultural University, Khulna, Bangladesh \\ *Corresponding author
}

A R T I C L I N F O A B S T R A C T

Research Article

The experiment was conducted at the Agronomy Field Laboratory, Bangladesh Agricultural University, Mymensingh, Bangladesh to investigate the influence of plant nutrient management on the yield performance of transplant Aman rice. The experiment comprised two Aman rice varieties viz. Binadhan-15 and Binadhan-16, and ten nutrient management viz. Recommended dose of

Received : 21/04/2021

Accepted : 16/12/2021 inorganic fertilizer (RDF) Urea-TSP-MoP-Gypsum-ZnSO 4 @ 150-110-70-60-5 kg ha ${ }^{-1}$, Cowdung @ $10 \mathrm{t} \mathrm{ha}^{-1}$, Poultry manure @ $5 \mathrm{t} \mathrm{ha}^{-1}$, Vermicompost @ $3 \mathrm{t} \mathrm{ha}^{-1}, 25 \%$ less than RDF + cowdung @ $5 \mathrm{t} \mathrm{ha}^{-1}, 50 \%$ less than RDF + cowdung@10 $\mathrm{t} \mathrm{ha}^{-1}, 25 \%$ less than RDF + poultry manure @ 2.5 $\mathrm{t} \mathrm{ha}^{-1}, 50 \%$ less than RDF + poultry manure @ $5 \mathrm{t} \mathrm{ha}^{-1}, 25 \%$ less than RDF + vermicompost @ 1.5 $\mathrm{t} \mathrm{ha}^{-1}, 50 \%$ less than RDF + vermicompost @ $3 \mathrm{t} \mathrm{ha}^{-1}$. The experiment was laid out in a randomized complete block design with three replications. Binadhan-15 produced taller plants $(97.86 \mathrm{~cm})$,

Keywords:

Aman rice

Fertilizer

HYV

Manure effective tillers hill ${ }^{-1}(6.28)$, grains panicle ${ }^{-1}$ (101.73), higher grain $\left(3.58 \mathrm{t} \mathrm{ha}^{-1}\right)$ and straw (4.99 $\mathrm{t} \mathrm{ha}^{-}$ ${ }^{1}$ ) yields compared to Binadhan-16. In case of nutrient management, 50\% less than RDF + poultry manure@ $5 \mathrm{t} \mathrm{ha}^{-1}$ produced taller plants $(101.1 \mathrm{~cm})$, effective tillers hill ${ }^{-1}(7.07)$, grains panicle ${ }^{-1}$ (105.1) and grain yield $\left(4.08 \mathrm{t} \mathrm{ha}^{-1}\right)$. The highest grain yield $\left(4.25 \mathrm{t} \mathrm{ha}^{-1}\right)$ was recorded in Binadhan15 fertilized with 50\% less than RDF + poultry manure @ $5 \mathrm{t} \mathrm{ha}^{-1}$ and the lowest grain yield (2.28 $\mathrm{t} \mathrm{ha}^{-1}$ ) was obtained in Binadhan-16 fertilized with vermicompost @ $3 \mathrm{t} \mathrm{ha}^{-1}$. So, it can be concluded that transplant Aman rice cv. Binadhan-15 fertilized with 50\% less than RDF + poultry manure @ $5 \mathrm{t} \mathrm{ha}^{-1}$ appears as the promising practice to obtain the highest grain yield.

\section{Introduction}

Bangladesh is predominantly an agrarian country where the agriculture sector contributes about $14.23 \%$ to the country's gross domestic product (GDP) and employs around $40.60 \%$ of total labour force (BBS, 2019). Agriculture in Bangladesh is mainly rice based as it is consumed as the staple food by 164 million people of our country and production of rice contributes one half of the agricultural GDP and one sixth of the national income in Bangladesh (BBS, 2018). Bangladesh is third among the rice producing countries of the world (Childs, 2020) since the geographic and agro-ecological conditions of Bangladesh are very congenial for rice cultivation. Among different rice group in Bangladesh, transplant Aman rice is the most important that contributed a lot to the total yield of rice. The area and production of milled rice are about 11.52 million hectares and 36.39 million tons, respectively (BBS, 2019) in Bangladesh. Among the total rice production, Aman rice occupies about 5.62 million hectares of land with an annual production of 14.06 million tons (BBS, 2019) by utilizing varied soil fertility levels and nutrient management. In case of rice production, variety plays an important role. Selection of an improved and certified rice varieties can play an important role in increasing rice productivity (Chandio and Yuansheng, 2018). Among different transplant Aman rice, Binadhan-15 and Binadhan-16 are the two promising varieties released by Bangladesh Institute of Nuclear Agriculture (BINA). The average yield of Aman rice (2.5 $\mathrm{t} \mathrm{ha}^{-1}$ ) (BBS, 2019) in Bangladesh is very low compared to other rice growing countries of Asia because of an increasing rate of population (1.37\%) (BBS, 2019) and decreasing rate of agricultural land (1\%) per annum (Hussain et al., 2006) which limits the horizontal expansion of rice area. However, now a days, cropping intensity of Bangladesh is 
$197 \%$ (BBS, 2019) and the organic matter content of most of our soils is below $1.5 \%$, and in many cases, it is less than $1 \%$ (BARC, 2005). That's why, to overcome this situation, an increase in rice production per unit area by nutrient management is the only alternative to bring selfsufficiency in food production. In all the agricultural systems, there is an irresistible a loss of plant nutrients. To maintain good soil health and optimum yields, agricultural fields should be treated with combined application of organic manures and inorganic fertilizers which accelerates microbial activity, increases nitrogen use efficiency and enhances the availability of native nutrients to plants, resulting in higher nutrient uptake rates (Narwal and Chaudhary, 2006; Lakshmi et al., 2012). Cowdung and poultry manure can play an important role to improving soil fertility status by supplying nutrients like nitrogen $(\mathrm{N})$, sulfur (S), potassium (K), and zinc ( $\mathrm{Zn}$ ) and also a good source of organic matter in rice crop production (Khanam et al., 2001; Mitchell and Tu, 2006). On the other hand, vermicompost as a soil additive increases both cationexchange and water-retention capacities and provides nutrients in the required amounts as it reduces the use of mineral fertilizers (Tejada and Gonzalez, 2008). In addition, by maintaining a balanced combination of organic and inorganic fertilizer in one side environment, soil and lives will remain safe. On the other hand, farmers cost of production will be reduced as well as productivity will also be increased. Again, yield performance of two HYV transplant Aman rice varieties viz. Binadhan-15 and Binadhan-16 under different nutrient management practices are limited in the world's research. Therefore, the present investigation was, therefore, undertaken to observe the effect of nutrient management on the yield performance of transplant Aman rice varieties.

\section{Materials and Methods}

\section{Experimental Site and Experimentation}

The research work was conducted at the Agronomy Field Laboratory, Bangladesh Agricultural University $\left(24^{\circ} 75^{\prime} \mathrm{N}\right.$ latitude and $90^{\circ} 50^{\prime} \mathrm{E}$ longitude at an altitude of $18 \mathrm{~m}$ above the sea level), Mymensingh which belongs to the non-calcareous dark grey floodplain soil under the Old Brahmaputra Floodplain Agroecological Zone (AEZ 9) (UNDP and FAO, 1988) during July to December 2017. The field was a medium high flat land with well drained silty-loam texture having $\mathrm{pH}$, organic matter, total nitrogen, available phosphorus $\left(\mathrm{P}_{2} \mathrm{O}_{5}\right)$ and potassium of the soil ranged from 5.9-6.5, 0.93\%, 0.13\%, $16.3 \mathrm{ppm}$ and $0.28 \%$, respectively (Chakraborty et al., 2020). The experiment consisted of two Aman rice varieties viz. Binadhan-15 and Binadhan-16 and ten nutrient management viz. Recommended dose of inorganic fertilizer (RDF) urea-TSP-MoP-Gypsum-ZnSO 4 @ 150110-70-60-5 kg ha-1, Cowdung @ $10 \mathrm{t} \mathrm{ha}^{-1}$, Poultry manure @ $5 \mathrm{t} \mathrm{ha}^{-1}$, Vermicompost @ $3 \mathrm{t} \mathrm{ha}^{-1}, 25 \%$ less than RDF + cowdung@5 tha-1,50\% less than RDF+cowdung@ $10 \mathrm{tha}^{-1}, 25 \%$ less than RDF + poultry manure @ $2.5 \mathrm{tha}$ 1 , 50\% less than RDF + poultry manure @ $5 \mathrm{t} \mathrm{ha}^{-1}, 25 \%$ less than RDF + vermicompost @ $1.5 \mathrm{t} \mathrm{ha}^{-1}, 50 \%$ less than $\mathrm{RDF}+$ vermicompost @ $3 \mathrm{tha}^{-1}$. The experiment was laid out in a randomized complete block design with three replications.

\section{Crop Husbandry}

Seeds of tested varieties were sown in the nursery beds on 5 July 2017. The experimental land was first opened with a tractor drawn disc plough followed by puddled thoroughly by repeated ploughing and cross ploughing with a country plough and subsequently levelled by laddering on 10 August 2017. Then, at the time of final land preparation, respective unit plots were fertilized with different levels of cowdung, vermicompost, poultry manure according to treatments. The manures were thoroughly mixed with the soil. The amount of nitrogen, phosphorus, potassium, sulphur and zinc required for each unit plot was calculated on $\mathrm{ha}^{-1}$ basis and applied in the form of urea, triple super phosphate muriate of potash, gypsum and zinc sulphate, respectively. Triple super phosphate, muriate of potash, gypsum and zinc sulphate were applied at final land preparation as per treatment requirements. Urea was applied in three equal splits at 15 , 30 and 45 days after transplanting (DAT). Thirty-five days old seedlings were transplanted on 11 August 2017 maintaining a spacing of $25 \mathrm{~cm} \times 15 \mathrm{~cm}$ using 2-3 seedlings hill ${ }^{-1}$. Intercultural operations were done as and when necessary for ensuring and maintaining the normal growth of the crop.

\section{Sampling, Harvesting and Processing}

Five hills (excluding border hills and central $1.0 \times 1.0$ m) area were selected randomly from each unit plot. The selected plants were uprooted to record data on crop characters and yield contributing characters. After sampling, central $1.0 \times 1.0 \mathrm{~m}$ was harvested at full maturity. Binadhan-15 was harvested on 15 November whereas Binadhan-16 was harvested on 18 November. The harvested crops of each plot were separately bundled, properly tagged and then brought to the threshing floor. Threshing was done manually. The grains were cleaned and sun dried to the moisture content of $14 \%$. Straws were also dried properly. Finally grain and straw yields per plot were recorded and converted to $\mathrm{tha}^{-1}$.

\section{Statistical Analysis}

The collected data were compiled and tabulated in proper form for statistical analysis. Data were analyzed following the analysis of variance (ANOVA) technique and mean differences were adjudged by Duncan's Multiple Range Test (DMRT) (Gomez and Gomez, 1984).

\section{Results and Discussion}

\section{Varietal Performance}

Yield and yield contributing characters of Aman rice differed significantly due to varietal differences except for plant height, number of non-effective tillers hill ${ }^{-1}$ and harvest index (Table 1). The higher number of total tillers hill $^{-1}$ (7.44) and effective tillers hill ${ }^{-1}(6.28)$ was recorded from Binadhan-15, while the lowest number of total tillers hill $^{-1}$ (7.21) and effective tillers hill ${ }^{-1}$ (6.01) was found in Binadhan-16. The differences in producing tillers hill ${ }^{-1}$ is assessed might be due to the variation in genetic constituents between the variety. Due to varietal characteristics production of total tillers hill ${ }^{-1}$ and effective tillers hill ${ }^{-1}$ varied significantly (Ray et al., 2015; Chowdhury et al., 2016). The longest panicle $(21.63 \mathrm{~cm})$ 
was obtained in Binadhan-15 compared to Binadhan-16 $(21.00 \mathrm{~cm})$. This result might be due to the genetic characteristics of the variety which were influenced by heredity. Panicle length was significantly influenced by variety (Shaha et al., 2014; Chakraborty et al., 2020). The highest number of grains panicle ${ }^{-1}(101.73)$ and total spikelets panicle $^{-1}$ (113.86) was achieved from Binadhan15 , while the lowest number of grains panicle ${ }^{-1}$ (94.42) and total spikelets panicle ${ }^{-1}$ (107.00) was received in Binadhan16. The lowest number of sterile spikelets panicle ${ }^{-1}$ (12.13) was recorded from Binadhan-15 and the highest number of sterile spikelets panicle ${ }^{-1}$ (12.59) was found in Binadhan16. The highest 1000 -grains weight $(23.87 \mathrm{~g})$ was obtained from Binadhan-15 and the lower 1000-grain weight (23.14 g) was recorded in Binadhan-16. Different sizes of the spikelets produced by the varieties that were partly controlled by genetic make-up of the varieties were mainly responsible for this variation in 1000-grains weight. Similar results were also reported by Jisan et al. (2014) and Sarkar et al. (2014). The highest grain (3.58 t ha-1) and straw yield (4.99 $\mathrm{t} \mathrm{ha}^{-1}$ ) were recorded in Binadhan-15, while the lowest grain $\left(3.08 \mathrm{tha}^{-1}\right)$ and straw yield $(4.31 \mathrm{t}$ $\mathrm{ha}^{-1}$ ) were produced in Binadhan-16. Yield differences might be due to the genetic differences of the varieties and it varies from variety to variety. The highest grain yield might be due to the fact that Binadhan-15 performed best in terms of yield contributing characteristics, which ultimately contributed to the highest grain yield. On the other hand, the highest number of total tillers hill ${ }^{-1}$ and other vegetative characters were responsible for the highest straw yield. Significant variation of grain and straw yield among the rice genotypes were reported elsewhere (Tyeb et al., 2013; Pal et al., 2016; Adhikari et al., 2018).

\section{Effect of Nutrient Management}

Nutrient management had a significant effect on all yield contributing characters and yield of Aman rice except panicle length (Table 2$)$. The tallest plant $(101.10 \mathrm{~cm})$ was recorded from $50 \%$ less than RDF + poultry manure @ $5 \mathrm{t}$ ha $^{-1}$ which was at par with $25 \%$ less than RDF + poultry manure@ $2.5 \mathrm{t} \mathrm{ha}^{-1}$ and recommended dose of inorganic fertilizer, while the shortest plant $(94.17 \mathrm{~cm})$ was found with vermicompost @ $3 \mathrm{tha}^{-1}$. The highest number of total tillers hill ${ }^{-1}$ (8.06) and effective tillers hill ${ }^{-1}$ (7.07) were obtained in $50 \%$ less than RDF + poultry manure @ $5 \mathrm{t} \mathrm{ha}$ ${ }^{1}$, while the lowest number of total tillers hill ${ }^{-1}$ (6.71) and effective tillers hill ${ }^{-1}$ (5.37) were found when fertilized with vermicompost @ $3 \mathrm{t} \mathrm{ha}^{-1}$. It is may be due to the enhanced and continuous supply of nutrients by the combination of poultry manure and inorganic fertilizer which probably favored the cellular activities during formation and development which led to better tiller production. Paul et al. (2019) reported that the combined application of inorganic fertilizers and poultry manure increased total and effective tillers hill ${ }^{-1}$. The lowest noneffective tillers hill ${ }^{-1}(0.99)$ was achieved from $50 \%$ less than RDF + poultry manure @ $5 \mathrm{t} \mathrm{ha}^{-1}$ and the highest noneffective tillers hill ${ }^{-1}$ (1.34) was received when fertilized with vermicompost @ $3 \mathrm{t} \mathrm{ha}^{-1}$. The highest number of grains panicle ${ }^{-1}(105.10)$ was recorded from $50 \%$ less than RDF + poultry manure @ $5 \mathrm{t} \mathrm{ha}^{-1}$ and the lowest number of grains panicle ${ }^{-1}$ (90.63) was found in vermicompost @ $3 \mathrm{t}$ $\mathrm{ha}^{-1}$. Number of grains panicle ${ }^{-1}$ increased with combined application of manures and inorganic fertilizers were reported elsewhere (Sarkar et al., 2016; Jahan et al., 2017; Paul et al., 2020). The lowest number of sterile spikelets panicle $^{-1}$ (10.70) was obtained from 50\% less than RDF + poultry manure @ $5 \mathrm{t} \mathrm{ha}^{-1}$ and the highest number of sterile spikelets panicle ${ }^{-1}$ (13.64) was observed in vermicompost (a) $3 \mathrm{t} \mathrm{ha}^{-1}$. The highest number of total spikelets panicle ${ }^{-1}$ (115.8) was achieved from $50 \%$ less than RDF + poultry manure@ $5 \mathrm{t} \mathrm{ha}^{-1}$ which was at par with $25 \%$ less than $\mathrm{RDF}+$ poultry manure @ $2.5 \mathrm{t} \mathrm{ha}^{-1}$ and the lowest number of total spikelets panicle ${ }^{-1}$ (104.3) was received in vermicompost @ $3 \mathrm{t} \mathrm{ha}^{-1}$. The highest 1000-grain weight $(27.28 \mathrm{~g})$ was recorded from $50 \%$ less than RDF + poultry manure@ $5 \mathrm{t} \mathrm{ha}^{-1}$ which was at par with $25 \%$ less than RDF + poultry manure @ $2.5 \mathrm{t} \mathrm{ha}^{-1}$ and the lowest 1000grain weight $(20.38 \mathrm{~g}$ ) was found in vermicompost @ $3 \mathrm{t}$ $\mathrm{ha}^{-1}$. Nutrient management increased the availability and uptake of essential plant nutrients of rice fields which ultimately leads to the accumulation of greater source and translocation of photosynthates into the sink resulting in higher 1000-grain weight (Suresh et al., 2013; Islam et al., 2015). The highest grain yield $\left(4.08 \mathrm{t} \mathrm{ha}^{-1}\right)$ was obtained from $50 \%$ less than RDF + poultry manure @ $5 \mathrm{t} \mathrm{ha}^{-1}$ and the lowest grain yield $\left(2.47 \mathrm{t} \mathrm{ha}^{-1}\right)$ was observed in vermicompost @ $3 \mathrm{t} \mathrm{ha}^{-1}$. The higher grain yield may be due to probably poultry manure with inorganic fertilizers provided adequate nutrients to plants and due to absorption of more nutrients, the crop improved the yield contributing characters viz. number of effective tillers hill ${ }^{-1}$, number of grains panicle ${ }^{-1}$ and 1000-grain weight, which ultimately resulted in the highest grain yield. Application of manure along with inorganic fertilizers greatly influence the grain yield of rice were reported elsewhere (Yasmin et al., 2015; Pal et al., 2016; Roy et al., 2017; Chakraborty et al., 2020). On the other hand, Paul et al. (2020) reported that soil aeration, water holding capacity and microbial activity of soil improved due to the application of poultry manure as an organic matter which ultimately increases nutrient uptake of the crop resulting in higher yield. The highest straw yield $\left(5.33 \mathrm{t} \mathrm{ha}^{-1}\right)$ was achieved from $50 \%$ less than RDF + poultry manure @ $5 \mathrm{t} \mathrm{ha}^{-1}$ and the lowest straw yield (3.87 $\mathrm{t} \mathrm{ha}^{-1}$ ) was obtained with vermicompost @ $3 \mathrm{t} \mathrm{ha}^{-1}$. Application of poultry manures with inorganic fertilizers influenced the vegetative growth in terms of plant height and number of total tillers hill ${ }^{-1}$, which resulted in higher straw yield. The combined application of inorganic fertilizers with manures produced the highest straw yield (Jahan et al., 2017; Ali et al., 2018; Paul et al., 2019). The highest harvest index $(43.33 \%)$ was recorded from $50 \%$ less than RDF + poultry manure @ $5 \mathrm{t} \mathrm{ha}^{-1}$ which was at par with $25 \%$ less than RDF + poultry manure @ $2.5 \mathrm{t} \mathrm{ha}^{-1}$ and the lowest harvest index (38.96\%) was found in vermicompost@ $3 \mathrm{t} \mathrm{ha}^{-1}$. Ali et al. (2018) reported that the harvest index was significantly increased by the application of poultry manure with inorganic fertilizers.

\section{Effect of Interaction Between Variety and Nutrient Management}

Number of total tillers hill ${ }^{-1}$, number of effective tillers hill $^{-1}$, number of grains panicle ${ }^{-1}$, number of total spikelets panicle $^{-1}$, grain yield and straw yield varied significantly due to the interaction effect of variety and nutrient management (Table 3). The highest number of total tillers 
hill $^{-1}$ (8.13) and effective tillers hill ${ }^{-1}(7.15)$ was recorded from Binadhan-15 fertilized with $50 \%$ less than RDF + poultry manure @ $5 \mathrm{t} \mathrm{ha}^{-1}$, while the lowest number of total tillers hill ${ }^{-1}$ (6.53) and effective tillers hill $^{-1}$ (5.17) were found in Binadhan-16 fertilized with vermicompost @ $3 \mathrm{t}$ $\mathrm{ha}^{-1}$. The highest number of grains panicle ${ }^{-1}(107.00)$ was obtained from Binadhan-15 fertilized with $50 \%$ less than $\mathrm{RDF}+$ poultry manure @ $5 \mathrm{t} \mathrm{ha}^{-1}$ which was at par with Binadhan-15 fertilized with 25\% less than RDF + poultry manure @ $2.5 \mathrm{t} \mathrm{ha}^{-1}$ and Binadhan-16 fertilized with 50\% less than RDF + poultry manure @ $5 \mathrm{t} \mathrm{ha}^{-1}$, while the lowest number of grains panicle ${ }^{-1}$ (90.09) were observed in Binadhan-16 fertilized with vermicompost @ $3 \mathrm{t} \mathrm{ha}^{-1}$. The highest number of total spikelets panicle ${ }^{-1}$ (117.20) was achieved from Binadhan-15 fertilized with 50\% less than $\mathrm{RDF}+$ poultry manure @ $5 \mathrm{t} \mathrm{ha}^{-1}$ which was statistically identical to Binadhan-15 along with $25 \%$ less than RDF + poultry manure@2.5 t ha $\mathrm{t}^{-1}$ and Binadhan-15 fertilized with recommended dose of inorganic fertilizer, while the lowest number of total spikelets panicle ${ }^{-1}$ (104.1) was received in Binadhan-16 fertilized with vermicompost @ 3 $\mathrm{t} \mathrm{ha} \mathrm{h}^{-1}$. The highest grain $\left(4.25 \mathrm{t} \mathrm{ha}^{-1}\right)$ (Figure 1) and straw yield $\left(5.50 \mathrm{t} \mathrm{ha}{ }^{-1}\right)$ were recorded from Binadhan-15 fertilized with $50 \%$ less than the recommended dose + poultry manure@ $5 \mathrm{t} \mathrm{ha}^{-1}$, while the lowest grain $(2.28 \mathrm{t}$ $\left.\mathrm{ha}^{-1}\right)$ and straw yield $\left(3.58 \mathrm{t} \mathrm{ha}^{-1}\right)$ were obtained in Binadhan-16 fertilized with vermicompost @ $3 \mathrm{tha}^{-1}$. This highest result was obtained due to nutrient management which allowed plant roots to uptake adequate nutrients and exhibited the best performance due to absorption of more nutrients and moisture resulted in better growth, yield contributing characteristics and finally yield of rice plant. On the other hand, the combined effect of variety and nutrient management had a positive effect on rice yield due to steady release and higher uptake of nutrients by plants was reported elsewhere (Sarkar et al., 2014; Laila et al., 2020).

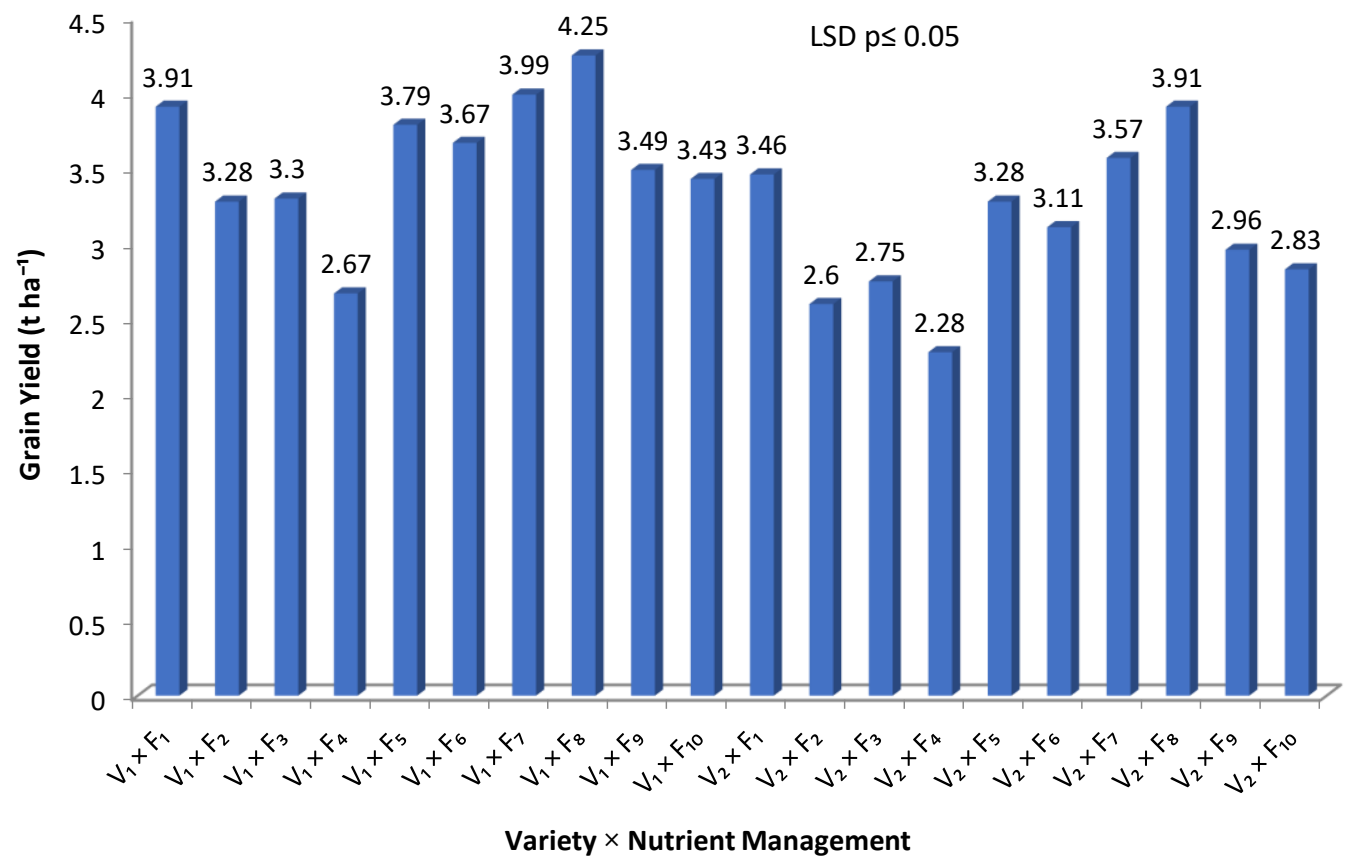

Figure 1. Interaction effects of variety and nutrient management on grain yield of transplant Aman rice $\mathrm{V} 1=$ Binadhan $-15, \mathrm{~V} 2=$ Binadhan -16

$\mathrm{F}_{1}=$ Recommended dose (Urea-TSP-MoP-Gypsum- $\mathrm{ZnSO}_{4} @ 150-110-70-60-5 \mathrm{~kg} \mathrm{ha}^{-1}, \mathrm{~F}_{2}=$ Cowdung @ $10 \mathrm{t} \mathrm{ha}^{-1}, \mathrm{~F}_{3}=$ Poultry manure @ $5 \mathrm{t}$ ha ${ }^{-1}, \mathrm{~F}_{4}=$ Vermicompost @ $3 \mathrm{tha}^{-1}, \mathrm{~F}_{5}=25 \%$ less than recommended dose + cowdung @ $5 \mathrm{t} \mathrm{ha}^{-1}, \mathrm{~F}_{6}=50 \%$ less than recommended dose + cowdung @ 10t ha ${ }^{-1}$, $\mathrm{F}_{7}=25 \%$ less than recommended dose + poultry manure @ $2.5 \mathrm{t} \mathrm{ha}^{-1}, \mathrm{~F}_{8}=50 \%$ less than recommended dose + poultry manure @ $5 \mathrm{t} \mathrm{ha}^{-1}, \mathrm{~F}_{9}=25 \%$ less than recommended dose + vermicompost @ $1.5 \mathrm{t} \mathrm{ha}^{-1}, \mathrm{~F}_{10}=50 \%$ less than recommended dose + vermicompost @ $3 \mathrm{t} \mathrm{ha}^{-1}$

Table 1. Effect of variety on yield and yield contributing characters of transplant Aman rice

\begin{tabular}{|c|c|c|c|c|c|c|c|c|c|c|c|c|}
\hline Variety & $\mathrm{PH}$ & TH & ETH & NTH & PL & GP & SSP & SP & GW & GY & SY & $\mathrm{HI}$ \\
\hline Binadhan -15 & 97.86 & $7.44^{\mathrm{a}}$ & $6.28^{\mathrm{a}}$ & 1.16 & $21.63^{\mathrm{a}}$ & $101.73^{\mathrm{a}}$ & $12.13 b$ & $113.86^{\mathrm{a}}$ & $23.87^{\mathrm{a}}$ & $3.58^{\mathrm{a}}$ & $4.99^{a}$ & 41.64 \\
\hline Binadhan-16 & 96.78 & $7.21^{\mathrm{b}}$ & $6.01^{b}$ & 1.20 & $21.00^{\mathrm{b}}$ & $94.42^{\mathrm{b}}$ & $12.59 \mathrm{a}$ & $107.00^{\mathrm{b}}$ & $23.14^{\mathrm{b}}$ & $3.08^{b}$ & $4.31^{\mathrm{b}}$ & 41.48 \\
\hline $\mathrm{Sx}$ & 0.573 & 0.016 & 0.014 & 0.016 & 0.193 & 0.416 & 0.109 & 0.441 & 0.192 & 0.015 & 0.024 & 0.170 \\
\hline $\mathrm{CV}(\%)$ & 3.23 & 1.17 & 1.25 & 7.42 & 4.96 & 2.33 & 4.82 & 2.19 & 4.48 & 2.53 & 2.84 & 2.24 \\
\hline Level of significance & NS & $* *$ & $* *$ & NS & $*$ & *** & *** & $* *$ & $* *$ & $* *$ & $* *$ & $\mathrm{NS}$ \\
\hline
\end{tabular}

PH: Plant height (cm), TH: Tillers hill ${ }^{-1}$ (no.), ETH: Effective tillers hill ${ }^{-1}$ (no.), NTH: Non-effective tillers hill ${ }^{-1}$ (no.), PL: Panicle length (cm), GP: Grains panicle $^{-1}$ (no.), SSP: Sterile spikelets panicle ${ }^{-1}$ (no.), SP: Spikelets panicle ${ }^{-1}$ (no.), GW: 1000- grain weight (g), GY: Grain yield (t ha-1), SY: Straw yield $\left(\mathrm{t} \mathrm{ha}^{-1}\right)$, HI: Harvest index (\%), In a column, figures with same letter (s) or without letter do not differ significantly whereas figures with dissimilar letter differ significantly (as per DMRT), $* *=$ Significant at $1 \%$ level of probability, ${ }^{*}=$ Significant at $5 \%$ level of probability, NS $=$ Not significant. 
Table 2. Effect of nutrient management on yield and yield contributing characters of transplant Aman rice

\begin{tabular}{|c|c|c|c|c|c|c|c|c|c|c|c|c|}
\hline NM & $\mathrm{PH}$ & TH & ETH & NTH & PL & GP & SSP & SP & GW & GY & SY & HI \\
\hline $\mathrm{F}_{1}$ & $98.83^{\mathrm{ab}}$ & $7.61^{\mathrm{c}}$ & $6.50^{\mathrm{c}}$ & $1.112^{\mathrm{de}}$ & 21.52 & $100.60^{\mathrm{bc}}$ & $11.79^{\mathrm{d}}$ & $112.40^{\mathrm{bc}}$ & $25.10^{\mathrm{bc}}$ & $3.68^{\mathrm{b}}$ & $5.05^{\mathrm{bc}}$ & $42.17^{\mathrm{bc}}$ \\
\hline $\mathrm{F}_{2}$ & $95.83^{b c}$ & $6.92^{g}$ & $5.62^{\mathrm{i}}$ & $1.300^{\mathrm{a}} \mathrm{b}$ & 20.96 & $94.76^{\mathrm{e}}$ & $13.42^{\mathrm{ab}}$ & $108.20^{\mathrm{d}}$ & $21.37^{\mathrm{gh}}$ & $2.94^{\mathrm{f}}$ & $4.20^{\mathrm{g}}$ & $41.17^{\mathrm{c}}$ \\
\hline $\mathrm{F}_{3}$ & $96.57^{\mathrm{bc}}$ & $6.99^{\mathrm{g}}$ & $5.71^{\mathrm{h}}$ & $1.277^{\mathrm{ab}}$ & 21.01 & $96.05^{\mathrm{de}}$ & $13.18^{\mathrm{ab}}$ & $109.20^{\mathrm{d}}$ & $21.81^{\mathrm{fg}}$ & $3.02^{f}$ & $4.30^{\mathrm{fg}}$ & $41.29^{\mathrm{bc}}$ \\
\hline $\mathrm{F}_{4}$ & $94.17^{\mathrm{c}}$ & $6.71^{\mathrm{h}}$ & $5.37^{j}$ & $1.340^{\mathrm{a}}$ & 20.79 & $90.63^{f}$ & $13.64^{\mathrm{a}}$ & $104.30^{\mathrm{e}}$ & $20.38^{\mathrm{h}}$ & $2.47^{\mathrm{g}}$ & $3.87^{\mathrm{h}}$ & $38.96^{\mathrm{d}}$ \\
\hline $\mathrm{F}_{5}$ & $96.83^{\mathrm{bc}}$ & $7.51^{\mathrm{d}}$ & $6.35^{\mathrm{d}}$ & $1.160^{\mathrm{cd}}$ & 21.32 & $98.92^{\mathrm{cd}}$ & $12.03^{\mathrm{d}}$ & $110.90^{\mathrm{bcd}}$ & $24.13^{\mathrm{cd}}$ & $3.53^{c}$ & $4.93^{c}$ & $41.75^{\mathrm{bc}}$ \\
\hline $\mathrm{F}_{6}$ & $96.73^{b c}$ & $7.40^{\mathrm{e}}$ & $6.21^{\mathrm{e}}$ & $1.185^{\mathrm{bcd}}$ & 21.22 & $98.51^{\mathrm{cd}}$ & $12.08^{\mathrm{d}}$ & $110.60^{\mathrm{bcd}}$ & $23.80^{\mathrm{de}}$ & $3.39^{\mathrm{d}}$ & $4.74^{\mathrm{d}}$ & $41.68^{b c}$ \\
\hline $\mathrm{F}_{7}$ & $99.77^{\mathrm{ab}}$ & $7.75^{\mathrm{b}}$ & $6.70^{\mathrm{b}}$ & $1.050^{\mathrm{ef}}$ & 21.56 & $101.90^{\mathrm{b}}$ & $11.60^{\mathrm{d}}$ & $113.50^{\mathrm{ab}}$ & $26.19^{\mathrm{ab}}$ & $3.78^{b}$ & $5.11^{\mathrm{b}}$ & $42.50^{\mathrm{ab}}$ \\
\hline $\mathrm{F}_{8}$ & $101.10^{\mathrm{a}}$ & $8.06^{\mathrm{a}}$ & $7.07^{\mathrm{a}}$ & $0.990^{\mathrm{f}}$ & 22.48 & $105.10^{\mathrm{a}}$ & $10.70^{\mathrm{e}}$ & $115.80^{\mathrm{a}}$ & $27.28^{\mathrm{a}}$ & $4.08^{\mathrm{a}}$ & $5.33^{\mathrm{a}}$ & $43.33^{\mathrm{a}}$ \\
\hline $\mathrm{F}_{9}$ & $96.70^{\mathrm{bc}}$ & $7.23^{f}$ & $6.02^{f}$ & $1.210^{\mathrm{bcd}}$ & 21.20 & $97.85^{\mathrm{cd}}$ & $12.34^{\mathrm{cd}}$ & $110.20^{\mathrm{cd}}$ & $22.77^{\mathrm{ef}}$ & $3.22^{\mathrm{e}}$ & $4.55^{\mathrm{e}}$ & $41.45^{\mathrm{bc}}$ \\
\hline $\mathrm{F}_{10}$ & $96.63^{b c}$ & $7.13^{f}$ & $5.90^{\mathrm{g}}$ & $1.235^{\mathrm{abc}}$ & 21.08 & $96.38^{\text {de }}$ & $12.83^{b c}$ & $109.20^{\mathrm{d}}$ & $22.27^{\mathrm{fg}}$ & $3.13^{\mathrm{e}}$ & $4.44^{\mathrm{ef}}$ & $41.35^{\mathrm{bc}}$ \\
\hline Sx & 1.28 & 0.034 & 0.032 & 0.036 & 0.432 & 0.931 & 0.243 & 0.985 & 0.430 & 0.034 & 0.055 & 0.380 \\
\hline CV (\%) & 3.23 & 1.17 & 1.25 & 7.42 & 4.96 & 2.33 & 4.82 & 2.19 & 4.48 & 2.53 & 2.84 & 2.24 \\
\hline $\mathrm{LS}$ & $*$ & $* *$ & $* *$ & $* *$ & NS & ** & $* *$ & $* *$ & $* *$ & $* *$ & $* *$ & $* *$ \\
\hline
\end{tabular}

NM: Nutrient management, LS: Level of significance, PH: Plant height (cm), TH: Tillers hill ${ }^{-1}$ (no.), ETH: Effective tillers hill ${ }^{-1}$ (no.), NTH: Noneffective tillers hill- ${ }^{-1}$ no.), PL: Panicle length (cm), GP: Grains panicle ${ }^{-1}$ (no.), SSP: Sterile spikelets panicle ${ }^{-1}$ (no.), SP: Spikelets panicle ${ }^{-1}$ (no.), GW: 1000- grain weight (g), GY: Grain yield $\left(\mathrm{t} \mathrm{ha}^{-1}\right)$, SY: Straw yield $\left(\mathrm{t} \mathrm{ha} \mathrm{H}^{-1}\right)$, HI: Harvest index (\%), In a column, figures with same letter (s) or without letter do not differ significantly whereas figures with dissimilar letter differ significantly (as per DMRT), *** =Significant at $1 \%$ level of probability, ${ }^{*}=$ Significant at $5 \%$ level of probability, NS = Not significant, $\mathrm{F}_{1}=$ Recommended dose (urea-TSP-MoP-Gypsum-ZnSO ${ }_{4} @ 150-110-70-$ 60-5 $\mathrm{kg} \mathrm{ha}^{-1}, \mathrm{~F}_{2}=$ Cowdung @ $10 \mathrm{tha}^{-1}, \mathrm{~F}_{3}=$ Poultry manure @ $5 \mathrm{t} \mathrm{ha}^{-1}, \mathrm{~F}_{4}=$ Vermicompost $@ 3 \mathrm{tha}^{-1}, \mathrm{~F}_{5}=25 \%$ less than recommended dose + cowdung @ $5 \mathrm{t} \mathrm{ha}^{-1}, \mathrm{~F}_{6}=50 \%$ less than recommended dose + cowdung @ $10 \mathrm{tha}^{-1}, \mathrm{~F}_{7}=25 \%$ less than recommended dose + poultry manure @ 2.5t ha ${ }^{-1}, \mathrm{~F}_{8}=50 \%$ less than recommended dose + poultry manure @ $5 \mathrm{t} \mathrm{ha}^{-1}, \mathrm{~F}_{9}=25 \%$ less than recommended dose + vermicompost @ $1.5 \mathrm{t} \mathrm{ha}^{-1}, \mathrm{~F}_{10}=50 \%$ less than recommended dose + vermicompost @ $3 \mathrm{tha}^{-1}$

Table 3. Interaction effects of variety and nutrient management on yield and yield contributing characters of transplant Aman rice

\begin{tabular}{|c|c|c|c|c|c|c|c|c|c|c|c|}
\hline $\mathrm{V} \times \mathrm{N}$ & $\mathrm{PH}$ & $\mathrm{TH}$ & ETH & NTH & PL & GP & SSP & SP & GW & SY & HI \\
\hline $\mathrm{V}_{1} \times \mathrm{F}_{1}$ & 98.20 & $7.73^{\mathrm{bc}}$ & $6.66^{\mathrm{d}}$ & 1.07 & 21.71 & $105.40^{\mathrm{ab}}$ & 11.53 & $116.90^{\mathrm{a}}$ & 25.60 & $5.34^{\mathrm{abc}}$ & 42.27 \\
\hline $\mathrm{V}_{1} \times \mathrm{F}_{2}$ & 96.33 & $6.97^{\mathrm{ij}}$ & $5.69^{\mathrm{klm}}$ & 1.28 & 21.24 & $97.88^{\mathrm{ef}}$ & 13.25 & $111.10^{\mathrm{bcd}}$ & 21.42 & $4.66^{\mathrm{fg}}$ & 41.27 \\
\hline $\mathrm{V}_{1} \times \mathrm{F}_{3}$ & 97.40 & $7.07^{\text {ghi }}$ & $5.80^{\mathrm{jk}}$ & 1.26 & 21.31 & $100.30^{\text {cde }}$ & 13.11 & $113.40^{\mathrm{abc}}$ & 22.22 & $4.68^{\mathrm{fg}}$ & 41.33 \\
\hline $\mathrm{V}_{1} \times \mathrm{F}_{4}$ & 95.47 & $6.89^{\mathrm{j}}$ & $5.57^{\mathrm{mn}}$ & 1.32 & 21.08 & $91.17^{\mathrm{h}}$ & 13.27 & $104.40^{\mathrm{f}}$ & 20.50 & $4.17^{\mathrm{ij}}$ & 39.03 \\
\hline $\mathrm{V}_{1} \times \mathrm{F}_{5}$ & 97.53 & $7.67^{c}$ & $6.53^{\mathrm{de}}$ & 1.14 & 21.60 & $103.60^{\mathrm{abc}}$ & 11.79 & $115.40^{\mathrm{ab}}$ & 24.60 & $5.27^{\mathrm{abc}}$ & 41.79 \\
\hline $\mathrm{V}_{1} \times \mathrm{F}_{6}$ & 97.53 & $7.60^{\mathrm{cd}}$ & $6.43^{\mathrm{ef}}$ & 1.17 & 21.56 & $103.30^{\mathrm{abc}}$ & 11.84 & $115.10^{\mathrm{ab}}$ & 24.00 & $5.12^{\mathrm{cd}}$ & 41.76 \\
\hline $\mathrm{V}_{1} \times \mathrm{F}_{7}$ & 99.73 & $7.83^{\mathrm{b}}$ & $6.80^{c}$ & 1.03 & 21.75 & $105.50^{\mathrm{ab}}$ & 11.49 & $116.90^{\mathrm{a}}$ & 27.02 & $5.38^{\mathrm{ab}}$ & 42.61 \\
\hline $\mathrm{V}_{1} \times \mathrm{F}_{8}$ & 101.40 & $8.13^{a}$ & $7.15^{\mathrm{a}}$ & 0.98 & 23.12 & $107.00^{\mathrm{a}}$ & 10.26 & $117.20^{\mathrm{a}}$ & 27.36 & $5.50^{\mathrm{a}}$ & 43.56 \\
\hline $\mathrm{V}_{1} \times \mathrm{F}_{9}$ & 97.53 & $7.33^{\mathrm{e}}$ & $6.14^{\mathrm{g}}$ & 1.19 & 21.55 & $102.20^{\mathrm{bcd}}$ & 12.29 & $114.50^{\mathrm{ab}}$ & 23.14 & $4.93^{\mathrm{de}}$ & 41.47 \\
\hline $\mathrm{V}_{1} \times \mathrm{F}_{10}$ & 97.47 & $7.27^{\mathrm{ef}}$ & $6.05^{\mathrm{gh}}$ & 1.22 & 21.38 & $101.00^{\text {cde }}$ & 12.52 & $113.50^{\mathrm{abc}}$ & 23.00 & $4.86^{\mathrm{ef}}$ & 41.37 \\
\hline $\mathrm{V}_{2} \times \mathrm{F}_{1}$ & 99.47 & $7.50^{\mathrm{d}}$ & $6.34^{\mathrm{f}}$ & 1.15 & 21.32 & $95.83^{\mathrm{fg}}$ & 12.06 & $107.90^{\mathrm{def}}$ & 24.60 & $4.76^{\mathrm{efg}}$ & 42.06 \\
\hline $\mathrm{V}_{2} \times \mathrm{F}_{2}$ & 95.33 & $6.87^{j}$ & $5.55^{\mathrm{n}}$ & 1.32 & 20.68 & $91.64^{\text {gh }}$ & 13.58 & $105.20^{f}$ & 21.32 & $3.73^{\mathrm{lm}}$ & 41.06 \\
\hline $\mathrm{V}_{2} \times \mathrm{F}_{3}$ & 95.73 & $6.92^{\mathrm{ij}}$ & $5.63^{\operatorname{lmn}}$ & 1.29 & 20.72 & $91.78^{\mathrm{gh}}$ & 13.25 & $105.00^{f}$ & 21.40 & $3.91^{\mathrm{kl}}$ & 41.24 \\
\hline $\mathrm{V}_{2} \times \mathrm{F}_{4}$ & 92.87 & $6.53^{\mathrm{k}}$ & $5.17^{\circ}$ & 1.36 & 20.51 & $90.09^{\mathrm{h}}$ & 14.01 & $104.10^{f}$ & 20.26 & $3.58^{\mathrm{m}}$ & 38.89 \\
\hline $\mathrm{V}_{2} \times \mathrm{F}_{5}$ & 96.13 & $7.35^{\mathrm{e}}$ & $6.17^{\mathrm{g}}$ & 1.18 & 21.05 & $94.21^{\text {fgh }}$ & 12.26 & $106.50^{\mathrm{ef}}$ & 23.66 & $4.58^{\mathrm{gh}}$ & 41.71 \\
\hline $\mathrm{V}_{2} \times \mathrm{F}_{6}$ & 95.93 & $7.20^{\mathrm{ef}} \mathrm{g}$ & $6.00^{\text {hi }}$ & 1.20 & 20.89 & $93.74^{\text {gh }}$ & 12.33 & $106.10^{\mathrm{ef}}$ & 23.60 & $4.36^{\mathrm{hi}}$ & 41.60 \\
\hline $\mathrm{V}_{2} \times \mathrm{F}_{7}$ & 99.80 & $7.67^{\mathrm{c}}$ & $6.60^{\mathrm{d}}$ & 1.07 & 21.36 & $98.27^{\text {def }}$ & 11.72 & $110.00^{\text {cde }}$ & 25.36 & $4.85^{\mathrm{ef}}$ & 42.39 \\
\hline $\mathrm{V}_{2} \times \mathrm{F}_{8}$ & 100.87 & $8.00^{\mathrm{a}}$ & $7.00^{\mathrm{b}}$ & 1.00 & 21.84 & $103.30^{\mathrm{abc}}$ & 11.14 & $114.50^{\mathrm{ab}}$ & 27.20 & $5.16^{\mathrm{bc}}$ & 43.10 \\
\hline $\mathrm{V}_{2} \times \mathrm{F}_{9}$ & 95.87 & $7.13^{\text {fgh }}$ & $5.90^{\mathrm{ij}}$ & 1.23 & 20.84 & $93.48^{\mathrm{gh}}$ & 12.39 & $105.90^{\mathrm{ef}}$ & 22.40 & $4.18^{\mathrm{ij}}$ & 41.44 \\
\hline $\mathrm{V}_{2} \times \mathrm{F}_{10}$ & 95.80 & $7.00^{\mathrm{hij}}$ & $5.75^{\mathrm{kl}}$ & 1.25 & 20.79 & $91.79^{\text {gh }}$ & 13.14 & $104.90^{f}$ & 21.55 & $4.01^{\mathrm{jk}}$ & 41.34 \\
\hline $\mathrm{Sx}$ & 1.81 & 0.048 & 0.045 & 0.052 & 0.611 & 1.31 & 0.344 & 1.39 & 0.608 & 0.077 & 0.537 \\
\hline CV $(\%)$ & 3.23 & 1.17 & 1.25 & 7.42 & 4.96 & 2.33 & 4.82 & 2.19 & 4.48 & 2.84 & 2.24 \\
\hline $\mathrm{LS}$ & $\mathrm{NS}$ & $*$ & $* *$ & $\mathrm{NS}$ & NS & $*$ & $\mathrm{NS}$ & $*$ & $\mathrm{NS}$ & $*$ & $\mathrm{NS}$ \\
\hline
\end{tabular}

$\mathrm{V} \times \mathrm{N}$ : Variety $\times$ Nutrient management, LS: Level of significance, PH: Plant height (cm), TH: Tillers hill-1 (no.), ETH: Effective tillers hill-1 (no.), NTH: Non-effective tillers hill-1(no.), PL: Panicle length (cm), GP: Grains panicle-1 (no.), SSP: Sterile spikelets panicle-1 (no.), SP: Spikelets panicle1 (no.), GW: 1000- grain weight (g), SY: Straw yield (t ha-1), HI: Harvest index (\%), In a column, figures with same letter (s) or without letter do not differ significantly whereas figures with dissimilar letter differ significantly (as per DMRT), ** =Significant at $1 \%$ level of probability, $*=$ Significant

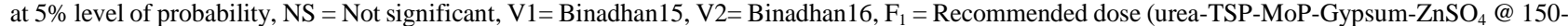
110-70-60-5kg ha ${ }^{-1}, \mathrm{~F}_{2}=$ Cowdung @ $10 \mathrm{t} \mathrm{ha}^{-1}, \mathrm{~F}_{3}=$ Poultry manure @ $5 \mathrm{t} \mathrm{ha}^{-1}, \mathrm{~F}_{4}=$ Vermicompost @ $3 \mathrm{t}$ ha ${ }^{-1}, \mathrm{~F}_{5}=25 \%$ less than recommended dose + cowdung@ $5 \mathrm{t} \mathrm{ha}^{-1}, \mathrm{~F}_{6}=50 \%$ less than recommended dose + cowdung @ $10 \mathrm{t} \mathrm{ha}^{-1}, \mathrm{~F}_{7}=25 \%$ less than recommended dose + poultry manure @ 2.5t ha ${ }^{1}, \mathrm{~F}_{8}=50 \%$ less than recommended dose + poultry manure @ $5 \mathrm{t} \mathrm{ha}^{-1}, \mathrm{~F}_{9}=25 \%$ less than recommended dose + vermicompost @ $1.5 \mathrm{t}$ ha ${ }^{-1}, \mathrm{~F}_{10}=50 \%$ less than recommended dose + vermicompost @ $3 \mathrm{t} \mathrm{ha}^{-1}$

\section{Conclusion}

According to the results of the experiment, Binadhan15 performed well considering most of yield components and grain yield. Among the different nutrient managements, $50 \%$ less than recommended dose of inorganic fertilizer + poultry manure @ $5 \mathrm{t} \mathrm{ha}^{-1}$ gave better performance. However, Binadhan-15 fertilized with 50\% less than recommended dose of inorganic fertilizer + poultry manure@ $5 \mathrm{t} \mathrm{ha}^{-1}$ gave the highest grain yield. So, 
it can be concluded that Binadhan-15 fertilized with $50 \%$ less than recommended dose of inorganic fertilizer + poultry manure @ $5 \mathrm{t} \mathrm{ha}^{-1}$ appeared as the promising practice in Aman rice cultivation in terms of grain yield.

\section{Conflict of Interest}

The authors declare that there is no conflict of interests regarding the publication of this paper.

\section{Acknowledgement}

The first author thankfully acknowledges the Ministry of Science and Technology of the Government of People's Republic of Bangladesh for funding this research project.

\section{References}

Adhikari A, Sarkar MAR, Paul SK, Saha KK. 2018. Impact of nutrient management on yield performance of some aromatic fine rice (Oryza sativa L.) varieties in Boro season. Archives of Agriculture and Environmental Science, 3(2): 245-251. https://doi.org/10.26832/24566632.2018.030306

Ali MI, Sarkar MAR, Paul SK. 2018. Influence of plant nutrient management on the yield performance of transplant Aman rice (Oryza sativa L.). Archives of Agriculture and $\begin{array}{lll}\text { Environmental } & \text { Science, } & \text { 3(1): }\end{array}$ https://doi.org/10.26832/24566632.2018.030106

BARC (Bangladesh Agricultural Research Council). 2005. Fertilizer Recommendation Guide, Bangladesh Agricultural Research Council,Farmgate, Dhaka.

BBS (Bangladesh Bureau of Statistics). 2018. Monthly Statistical Bulletin, Ministry of Planning. Goverment of the People's Republic of Bangladesh. Dhaka. pp. 49-69.

BBS (Bangladesh Bureau of Statistics). 2019. The Statistical Year Book of Bangladesh. Statistics Division, Ministry of Planning, Government of People's Republic of Bangladesh, Dhaka. p. 47.

BBS (Bangladesh Bureau of Statistics). 2019. The Yearbook of Agricultural Statistics of Bangladesh. Statistics Division, Ministry of Planning, Government of People's Republic of Bangladesh, Dhaka. pp. 02-434.

Chakraborty S, Rahman A, Salam MA. 2020. Effect of integrated nutrient management on the growth and yield of Boro rice (Oryza sativa L.) cultivars. Archives of Agriculture and $\begin{array}{lll}\text { Environmental } & \text { Science, } & \text { 5(4): }\end{array}$ https://doi.org/10.26832/24566632.2020.050407

Chandio AA, Yuansheng J. 2018. Determinants of adoption of improved rice varieties in northern sindh, Pakistan. Rice Science, 25(2): 103-110. http://dx.doi.org/10.1016/j.rsci.2017.10.003

Childs N. 2020. RCS-20E, U.S Department of Agriculture, Economic Research Service, May 14, 2020. p.7.

Chowdhury SA, Paul SK, Sarkar MAR. 2016. Yield performance of fine aromatic rice in response to variety and level of nitrogen. Journal of Environmental Science and Natural Resources, 9 (1): 41-45.

Gomez KA, Gomez AA. 1984. Statistical Procedure for Agricultural Research, $2^{\text {nd }}$ Edn. Jhon Wiley and Sons, Newyork, Chickester, Brisbane, Toronto, Singapore. p. 680.

Hussain MM, Alam MS, Islam MA, Rashid MM, Islam MF, Rashid MA, Razzaque MS, Mamun MSI, Islam MR, Kabir H, Parvin S, Mukul HR. 2006. In Proceedings: Twenty first BRRI-DAE Joint Workshop. Bangladesh Rice Res. Inst., Joydebpur, Gazipur, Bangladesh. September 19-21, 2006. pp. $1-3$.
Islam SMM, Paul SK, Sarkar MAR. 2015. Effect of weeding regime and integrated nutrient management on yield contributing characters and yield of BRRI dhan49. Journal of Crop and Weed, 11(Special Issue): 193-197.

Jahan S, Sarkar MAR, Paul SK. 2017. Effect of plant spacing and fertilizer management on the yield performance of BRRI dhan39 under old Brahmaputra floodplain soil. Madras Agricultural Journal, 104(1-3): 37-40.

Jisan MT, Paul SK, Salim M. 2014. Yield performance of some transplant Aman rice varieties as influenced by different level of nitrogen. Journal of Bangladesh Agricultural University, 12: 321-24.

Khanam M, Rahman MM, Islam MR, Islam MR. 2001. Effect of manures and fertilizers on the growth and yield of BRRI dhan30. Pakistan Journal of Biological Sciences, 4: 172-174. https://doi.org/10.3923/pjbs.2001.172.174

Laila N, Sarkar MAR, Paul SK, Rahman A. 2020. Yield performance of aromatic fine rice as influenced by integrated use of vermicompost and inorganic fertilizers. Journal of Bangladesh Agricultural University, 18(2): 260-265. https://doi.org/10.5455/JBAU.90309

Lakshmi CSR, Rao PC, Sreelatha T, Mahadevi M, Padmaja G, Rao PV, Sireesha A. 2012. Nitrogen use efficiency and production efficiency of rice under rice-pulse cropping system with integrated nutrient management. Journal of Rice Research, 5: 42-51.

Mitchell CC, Tu S. 2006. Nutrient accumulation and movement from poultry litter. Soil Science Society of America Journal, 70: 2146-2153.

Narwal RP, Chaudhary M. 2006. Effect of long-term application of FYM and fertilizer $\mathrm{N}$ on available $\mathrm{P}, \mathrm{K}$ and $\mathrm{S}$ content of soil. 18th World Congress of Soil Science, Philadelphia, Pennsylvania, 9-15 July 2006.

Pal S, Paul SK, Sarkar MAR, Gupta DR. 2016. Response on yield and protein content of aromatic fine rice varieties to integrated use of cowdung and inorganic fertilizers. Journal of Crop and Weed, 12(1): 01-06.

Paul SK, Nila NY, Sarkar MAR. 2020. Grain yield and quality of aromatic Boro rice (cv. BRRI dhan50) subject to date of transplanting and nutrient management. Thai Journal of Agricultural Science, 53(2): 85-96.

Paul SK, Ray MC, Sarkar MAR, Sarkar SK. 2019. Effect of water, nutrient and weed management on the yield and quality of aromatic Boro rice (CV. BRRI dhan50). Bangladesh Agronomy Journal, 22 (1): 57-69.

Ray S, Sarkar MAR, Paul SK, Islam AKMM, Yeasmin S. 2015. Variation of growth, yield and protein content of transplant Aman rice by three agronomic practices. Agricultural and Biological Sciences Journal, 1: 167-76.

Roy P, Sarkar MAR, Paul SK. 2017. Yield and Grain Protein Content of Aromatic Boro Rice (cv. BRRI dhan50) as Influenced by Integrated Fertilizer and Weed Management. International Journal of Applied Sciences and Biotechnology, 5(1): 51-58. https://doi.org/ 10.3126/ijasbt.v5i1.17008

Sarkar SK, Sarkar MAR, Islam N, Paul SK. 2014. Yield and quality of aromatic fine rice as affected by variety and nutrient management. Journal Bangladesh Agricultural University, 12(2): 279-284.

Sarkar SK, Sarkar MAR, Islam N, Paul SK. 2016. Morphophysiological attributes of three HYV aromatic fine rice varieties as affected by integrated nutrient management. Journal of Agroforestry and Environmental science, 10(1): $57-61$.

Shaha U, Bhuiya MSU, Paul SK. 2014. Integrated use of cowdung and inorganic fertilizer on the performance of modern varieties of transplanted Aman rice. Journal of Agroforestry and Environment, 8: 81-84. 
Suresh K, Reddy GR, Hemalatha S, Reddy SN, Raju AS, Madhulety TY. 2013. Integrated nutrient management in rice: A critical review. International Journal of Applied Biology and Pharmaceutical Technology, 4(2): 47-53.

Tejada M, Gonzalez JL. 2008. Application of two vermicomposts on a rice crop: effects on soil biological properties and rice quality and yield. Agronomy Journal, 101: 336-344.

Tyeb A, Paul SK, Samad MA. 2013. Performance of variety and spacing on the yield and yield contributing characters of transplanted Aman rice. Journal of Agroforestry and Environment, 40: 595-97.
UNDP and FAO. 1988. Land Resources Appraisal of Bangladesh for Agricultural Development. Report 2. Agro-ecological Regions of Bangladesh. Bangladesh Agricultural Research Council, Dhaka-1207. pp 212-221.

Yasmin R, Paul SK, Paul SC, Salim M. 2015. Effect of plant spacing and integrated nutrient management on the yield performance of Binadhan-14. Archives of Agriculture and Environmental Science, 3(4): 354-359. https://doi.org/10.26832/24566632.2018.030404 